\title{
Impact of Cashflow Volatility on Cash-Cash Flow Sensitivity of Pakistani Firms
}

\author{
${ }^{1}$ Sehrish Ahsan, ${ }^{2}$ Naeem Ullah \\ ${ }^{1,2}$ Foundation University Institute of Engineering and Management Sciences
}

\begin{abstract}
This study is conducted to observe the impact of cash flow volatility (CVCF) on cash-cash flow sensitivity of Pakistani Manufacturing Firms by taking a panel data of 377 manufacturing firms listed on Karachi Stock Exchange. The test revealed that cash flow volatility had significant impact on cash-cash flow sensitivity. This sensitivity was due to the precautionary motive of Pakistani Manufacturing Firms. Further, cash-cash flow sensitivity was studied by classifying firms into constrained and unconstrained categories by using cash flow volatility $(\mathrm{CVCF})$ and size. The results for the classification based on cash flow volatility $(C V C F)$ reveals that cash-cash flow sensitivity is more due to long-term debt for constrained firms and due to sales growth for unconstrained firms. The results for the classification based on size reveals that cash-cash flow sensitivity is present in both constrained and unconstrained firms. However, in constrained firms this sensitivity is mainly due to growth opportunities available to those firms. While in unconstrained firms this sensitivity can be attributed to increase leverage and resultant increased in cash flow volatility $(C V C F)$ due to leverage.
\end{abstract}

\section{Introduction}

According to Fisher separation theorem, the sole objective of a firm is to maximize the present value. The theorem faces three different counter opinions based on investment. The first claim is about the separation of firm's investment decisions from that of its owners. The second claim states about the difference of financing decisions between the firm and its owners. And lastly, there is no use of mix method to finance the firm's investment. Hence, the way the business is run, does not depend on how the firm is financed or how the dividends are paid to its owners, it depends upon available market opportunities.

Keynesian theory is also called liquidity preference approach because it deals with the demand of liquid assets cash. Cash Management can be divided into three kinds of motives, which drive the demand for cash. It includestransaction motive, precautionary motive and speculative motive. According to Keynes, precautionary motive is of great attention and the desire to save money or part of resources. The aim of this demand theory is to reach cash balance which is further divided into two kinds; active cash balance and idle cash balance. Keynes further noted two more motives for cash holdings by firms. Firstly, cash holding prevents a firm to avoid transactions necessary to access external finance and secondly, the precautionary motive which helps the firms to save money for unforeseen conditions.

Asymmetric Information also plays an important role in cash holding. According to Harford et al. (2005) when information asymmetry is high the probability of holding cash also increases because then the managers resist distributing the cash to shareholders.

Cash flow volatility has a significant impact on the amount of financial slack a firm maintains and on its investment-cash flow sensitivity. Firms with high cash flow volatility maintain higher levels of financial slack than their rivals with low cash flow volatility and that the investment outlays of these firms are less sensitive to the firm's internallygenerated cash flows (Cleary et al. 2006). The impact of cash flow volatility on a firm's cash holdings depend on a firm's financial constraint status. The financially constrained firm increases its cash holdings in response to an increase in cash flow volatility. In contrast, the cash holdings of financially unconstrained firms are not sensitive to cash flow volatility (Seungjin Han et al. 2007).

Firms with high level of financial constraints tend to hold cash as compared to when firms are not constrained. Investment opportunity also acts as a factor that affects cash flows. According to study performed byRan Duchin (2007), an inverse correlation was found between the precautionary demand and the investment. By holding cash for precautionary motives it provides liquidity and helps face future uncertainty regarding external finance.

According to Fazzari et al. (1988), cash flow sensitivity should be high for those firms with financial constraints which also depict a segment between internal and external costs. An inverse relation was found between cash flow sensitivity and marginal value of cash such that when firms have little cash then the marginal cost of spending cash increases significantly. Hence, a firm's marginal value of cash is a key factor for determining the financing choices which are further revealed by cash flow sensitivities. 


\section{Literature Review}

According to Fisher Separation Theorem the sole objective of a firm is to maximize the present value irrespective of the firm owner's preference. The theorem faces three different counter opinions based on investment. The first claim is about the separation of firm's investment decisions from that of its owners. Likewise, the second claim states the same point about the difference of financing decisions between the firm and its owners. And lastly, there is no use of mix method to finance the firm's investment. Hence, the way the business is run does not depend on how the firm is financed or how the dividends are paid to its owners. As the firms operate irrespective of the investments so to obtain an ideal state, it solely depends on the available market opportunities. Further, the Fisher Theorem goes well with the perfect market concept because in that case the manager's main focus is to take up investing strategies which lead to greater profits. In another study; it was observed that in the presence of perfect capital markets the consumer's investment and consumption decisions are independent.

Keynesian theory is also called liquidity preference approach because it deals with the demand of cash which is considered the most liquid asset and so this theory deals with the preference or demand of liquid asset. Cash Management can be divided into three kinds of motives, which drive the demand for cash includes:

\section{$\checkmark$ Transaction motive \\ $\checkmark$ Precautionary motive \\ $\checkmark$ Speculative motive}

According to Keynes,precautionary motive is of immense consideration and the desire to save money or part of resources. The main idea is to look for cheap and reliable ways of obtaining cash so it can be reimbursed easily when needed.Nguyen (2005) examined that precautionary motive drives the need to have a cash balance which ultimately lessens the instability of earnings which is also a measure of risk.

The aim of this demand theory is to reach cash balance which is further divided into two kinds; active cash balance and idle cash balance. Active cash balance implies for the demand under transaction and precautionary motive because in both these motives the demand for cash is highly active. On the other hand, speculative motive comes under idle cash balance because the demand for cash is not high and is only need for uncertain conditions. Keynes suggested that the demand for money is not about what people actually have in hand as suggested by Fisher but what amount money balances they wish to hold.

Kim et al. (1998) studied about thefirm's optimal cash holdings and investment policy and he did not emphasizeon the precautionary motive for cash holdings. They assume that cash holdings and short-term investments are alternatives for future liquidity requirements. Consequently, the optimal decisions on short-term investments and cash holdings are decided by the exchange between short-term investments and cash holdings. Kim et al. (1998)predicts that only a financially unconstrained firm with an extra cash endowment has less marginal return on short-term investmentsthan the risk free rate, so it holds a positive amount of cash while a financially constrained firm holds no cash. Therefore, the motive for a firm to hold positive cash is due to an extra cash endowment and not for the precautionary motive.

According to Fazzari et al. (1988), cash flow sensitivity should be high for those firms with financial constraints which also depict a segment between internal and external costs. Firms with high growth rates, low dividend payout ratio and smaller size have considerably higher cash flow sensitivity.Autore and Kovacs (2005) observed that when information asymmetry is low firms refer to external financial markets and also issue equity. According to Lundstrum (2003), a firm's value can be enhanced when internal capital markets are accessed. Moreover, for a high firm value it is also necessary that information asymmetry must be low.

Opler et al. (1999) was of the opinion that cash flow and cash flow volatility had significant impact on firm's cash holdings. They found that higher cash flow results in higher cash holdings. Similarly, cash flow volatility was responsible for higher cash holdings due to precautionary motives of the firm.

The work of Almeida et al. (2004) indicated that constrained firms show greater cash to cash flow sensitivity as compared to unconstrained firms. This study was further elaborated by Acharya in 2006, who added investment opportunity as a factor which affects cash flows. An inverse correlation was found between the two. This relation was then taken in money demands perspective and the result suggested that with the help of external funds better investments take place but in return the precautionary motive for cash holding becomes least valued. However, when the investment or business risk is high the precautionary demand plays an important role in order to reserve cash.Asymmetric Information also plays an important role in cash holding. When information asymmetry is high the probability of holding cash also increases because then the managers resist distributing the cash to shareholders(Harford, Mansi and Maxwell, 2005).

Ferreira and Vilela (2004) considered the elements of corporate cash holdings and showed that with greater investment opportunities there will be increase in cash holdings and hence the cash flow. However, the cash holdings are negatively affected by assets liquidity, leverage and firm size.

Dittmar (2003) worked on the importance of corporate governance in defining the cash holdings and discovered that the countries where the firms have low shareholder protection hold more cash as compared to 
those with higher protection. Furthermore, when cash is easily available, there is a higher chance of holding more cash.

Hofmann (2006) investigated the effect of corporate cash holdings on non-financial firms and based on that he proposed that the main factors of corporate cash holdings are growth opportunities, cash flow variability and leverage \& dividend payment. Among these factors, dividend payment is inversely proportional to cash holdings.

In addition to better investment opportunities and high growth rates, firms with high cash holdings also have a better operating performance (Opler, et al., 1999; Mikkelson and Partch, 2003). However, it was observed that high cash holdings also indicate poor corporate governance (Dittmar, Mahrt-Smith and Servaes, 2003; Ferreira and Vilela, 2004; Ozkan and Ozkan, 2004; Kusnadi, 2005; Chang and Noorbakhsh, 2006). Another research found that when shareholder protection is low then cash holdings pose a negative effect on the value of firm (Kalcheva and Lins, 2006; Pinkowitz, Stulz and Williamson, 2006).

\subsection{Data}

\section{Methodology}

This data is gathered from non-financial firms of Pakistan because banks and other financial institutions are under the direction of State Bank of Pakistan to maintain cash reserves. These statutory liquidity requirements hinder liquidity to come up with generalized and robust relationship of cash-cash flow sensitivity and the impact of volatility on demand. We will take on the firms registered on Karachi Stock Exchange. However, those firms which have incomplete record for the study period will be prolonged.

Data for computing variables will be obtained from Balance Sheet Analysis by State Bank of Pakistan. This source of data is considered because it is published by an authentic government body and the figures are more reliable.

\subsection{Sample Period}

In period, the study is conducted from 2005-2010, where 2005 will be used for the calculation of lag variables where and when required. Thus, our estimation period will start from 2006 and ends in 2010. This estimation period had significant volatility in Pakistan because the economy was booming and flourishing in 2006. In 2007, the economy faced recession from declining period to crises period and then recovered in 2009 and 2010. Thus, this period has hallmark of possible shocks that the firms may face with the respect of their cash flows and consistency cash holdings.

\subsection{Model}

In order to check the impact of volatility on cash holdings, we will augment Almeida et al. (2004) model with cash flow volatility.

Where,

$$
\mathrm{CASH}_{(\mathrm{i}, \mathrm{t})}=\alpha_{\mathrm{i}, \mathrm{t}}+\beta_{1} \mathrm{CF}_{\mathrm{i}, \mathrm{t}}+\beta_{2} \mathrm{CVCF}_{\mathrm{i}, \mathrm{t}}+\beta_{3} \mathrm{SIZE}_{\mathrm{i}, \mathrm{t}}+\beta_{4} \mathrm{LEV}_{\mathrm{i}, \mathrm{t}}+\mathrm{SG}_{\mathrm{i}, \mathrm{t}}+\varepsilon_{\mathrm{i}, \mathrm{t}}
$$

$$
\text { Cashflow }=\frac{(\text { EBT }+ \text { Dep })}{\text { Total Assets }- \text { Cash }}
$$

Now we will measure the cash flow by using the above formula and deflate it by total assets less cash. Cash is deducted because our dependent variable is cash itself.

CVCF is the cash flow volatility which is obtained by GARCH variance series conducting following $\operatorname{GARCH}(1,1)$ equation:

$$
\mathrm{CF}_{\mathrm{t}}=\alpha+\beta_{1}(\mathbf{C F})_{\mathrm{t}-1}+\varepsilon_{\mathrm{t}}
$$

GARCH series obtained by conducting this equation is more valid than the standard deviation because standard deviation requires lots of observations which are limited in the case of Pakistan where the firm's long-term records are unavailable. However, GARCH variance series is designed to extract deviation observation by observation and thus is more robust.

$$
\text { Size }=\ln (\text { Total Assets })
$$

Firm size is measured by the natural logarithm of total assets. It depends upon economies of scale in cash management where large firms may have a lower cash-to-assets ratio than small firms.

$$
\text { LEV }=\frac{\text { Long }- \text { Term Debts }}{\text { Total Assets }- \text { Cash }}
$$

Leverage is measured by long-term debt divided by total assets less cash. Firms with higher leverage levels might need to save more cash to meet future debt payments.

$$
\text { Sales Growth }=\ln \left[\frac{\frac{\text { Sales }_{t}}{\text { TA }_{t}-\text { Cash }_{t}}}{\frac{\text { Sales }_{t-1}}{\mathrm{TA}_{\mathrm{t}-1}-\text { Cash }_{\mathrm{t}-1}}}\right]
$$


Sales growth is measured by sales divided by total assets less cash and then taking natural logarithm of current period. Divide the nominator by denominator of sales divide total assets less cash of the previous period.

\section{Analytic Model}

Following panel data analytical model will be used:
a) Common effect model
b) Fixed effect model
c) Random effect model
d)

\subsection{Common Effect Model}

Common effect model in panel data is assumed as identical characteristics across the sample and thus may give biased results if the sample consists of un-identical firms. All firms have one characteristic in common and that is non-financial firms.

\subsection{Fixed Effect Model}

Fixed effect model has fixed intercept for all the firms in the sample but also allow for changes in the characteristics of the firms. This model is more ideally suited for all analysis where we have to take the firms from all industries. By taking fixed intercept for all the firms, it controls the effect of omitted variables in the regression equation.

\subsection{Random Effect model}

Random effect model takes into account the biasness generated by the error term. Further it has no different intercept point that is as industries changes its intercept.

According to Gujarati (2003), when a lot of data is taken within a limited time period it causes random effect model and fixed effect model to give conflicting results. In order to determine whether to accept the results of fixed effect model or random effect model then we will use Haussmann test under following hypothesis:

\section{$H_{0}$ : Results of fixed effect model are not accepted.}

$\mathrm{H}_{1}$ : Results of fixed effect model are accepted.

By conducting Haussmann test these hypothesis are p-values of 0.05 or less will make us accept the results of fixed effect model and vice-versa.

\subsection{Heteroskedasticity}

The inheritance probably with regression analysis is the present of outliers in the data. These outliers create an unconstrained variance that may make commit to type 1 and type 2 errors. In order to estimate heteroskedasticity we will employ Breusch-Pagan/ Cook-Weisberg test under the following hypothesis:

$$
\begin{array}{r}
\mathrm{H}_{0} \text { : Constant variance } \\
\mathrm{H}_{1} \text { : Inconstant variance }
\end{array}
$$

\subsection{All Firms Descriptive}

TABLE 1

\begin{tabular}{|c|c|c|c|}
\hline Variable & Observations & Mean & Std. Dev. \\
\hline CASH & 1885 & 0.0592209 & 0.1876429 \\
\hline CF & 1885 & 0.0984673 & 0.2824739 \\
\hline CVCF & 1885 & 0.7019582 & 11.71111 \\
\hline SIZE & 1885 & 14.31084 & 1.790839 \\
\hline LEV & 1885 & 0.2351955 & 0.8174534 \\
\hline SG & 1885 & -0.0142513 & 0.5318739 \\
\hline
\end{tabular}

It is evident from the descriptive that Pakistani firms hold more cash out of cash flow because the mean of cash flow is 0.09 while that of cash and cash flow are 0.059 and 0.089 respectively. This indicates that almost $9 \%$ cash flow's corresponding cash holdings are almost $6 \%$. Thus, we will expect high cash to cash sensitivity. Similarly, CVCF is almost $70 \%$. This high cash holding may be due to high cash flow volatility. 


\subsection{Correlation Matrix}

TABLE 2

\begin{tabular}{|c|c|c|c|c|c|c|}
\hline Variable & Cash & Cash flow & CVCF & Size & Leverage & $\begin{array}{c}\text { Sales } \\
\text { Growth }\end{array}$ \\
\hline CASH & 1.00000 & & & & & \\
\hline CF & 0.3775 & 1.0000 & & & & \\
\hline CVCF & 0.1948 & 0.0507 & 1.0000 & & & \\
\hline SIZE & -0.0342 & -0.0289 & -0.1047 & 1.0000 & & \\
\hline LEV & 0.3558 & 0.0357 & 0.3032 & -0.1653 & 1.0000 & \\
\hline SG & 0.0097 & 0.0478 & 0.0025 & -0.0306 & 0.0011 & 1.0000 \\
\hline
\end{tabular}

The correlation matrix has been included to check for multicollinearity. It is evident from the correlation of 0.5 or more that the independent variables will be the indication of multicollinearity. The highest correlation is between leverage and cash flow which is about $30 \%$. Thus, correlation matrix proves beyond doubt that no problem of multicollinearity exists among our variables.

\subsection{All Firms}

TABLE 3

\begin{tabular}{|c|c|c|c|c|c|c|c|}
\hline \multirow{4}{*}{$\begin{array}{c}\text { Common } \\
\text { Effect }\end{array}$} & Variables & Coefficient & $\begin{array}{c}\text { Robust } \\
\text { Std. Err. }\end{array}$ & $\mathbf{T}$ & P>|t| & \multicolumn{2}{|c|}{ [95\% Conf. Interval] } \\
\cline { 2 - 8 } Model & CVCF & 0.241264 & 0.0571686 & 4.22 & 0 & 0.1291435 & 0.353385 \\
\cline { 2 - 8 } & SIZE & 0.001315 & 0.0008069 & 1.63 & 0.103 & -0.000268 & 0.002897 \\
\cline { 2 - 8 } & LEV & 0.074439 & 0.0038223 & 1.05 & 0.294 & -0.003486 & 0.011507 \\
\cline { 2 - 8 } & SG & -0.002495 & 0.0202127 & 3.68 & 0 & 0.0347971 & 0.114081 \\
\cline { 2 - 8 } & Constant & -0.040397 & 0.0548154 & -0.26 & 0.799 & -0.021661 & 0.016671 \\
\hline
\end{tabular}

\begin{tabular}{|c|c|c|c|c|c|c|c|}
\hline \multirow{7}{*}{$\begin{array}{l}\text { Fixed } \\
\text { Effect } \\
\text { Model }\end{array}$} & Variables & Coefficient & $\begin{array}{c}\text { Robust } \\
\text { Std. Err. }\end{array}$ & $\mathbf{T}$ & $\mathbf{P}>|\mathbf{t}|$ & \multicolumn{2}{|c|}{ [95\% Conf. Interval] } \\
\hline & $\mathbf{C F}$ & 0.0684697 & 0.0218101 & 3.14 & 0.002 & 0.0256883 & 0.1112512 \\
\hline & CVCF & 0.0002528 & 0.000085 & 2.97 & 0.003 & 0.0000861 & 0.0004195 \\
\hline & SIZE & -0.0175164 & 0.0068374 & -2.56 & 0.011 & -0.0309283 & -0.004104 \\
\hline & LEV & 0.0383233 & 0.0062701 & 6.11 & 0 & 0.0260243 & 0.0506223 \\
\hline & SG & 0.0136691 & 0.0075983 & 1.8 & 0.072 & -0.0012354 & 0.0285735 \\
\hline & Constant & 0.2941568 & 0.097715 & 3.01 & 0.003 & 0.1024846 & 0.485829 \\
\hline
\end{tabular}

\begin{tabular}{|c|c|c|c|c|c|c|c|}
\hline & Variables & Coefficient & $\begin{array}{c}\text { Robust } \\
\text { Std. Err. }\end{array}$ & $\mathbf{Z}$ & $\mathbf{P}>|\mathbf{z}|$ & \multicolumn{2}{|c|}{$[\mathbf{9 5 \%}$ Conf. Interval] } \\
\cline { 2 - 8 } Random & $\mathbf{C F}$ & 0.0995434 & 0.0407661 & 2.44 & 0.015 & 0.0196434 & 0.1794434 \\
\cline { 2 - 8 } $\begin{array}{c}\text { Effect } \\
\text { Model }\end{array}$ & $\mathbf{C V C F}$ & 0.0004219 & 0.0003415 & 1.24 & 0.217 & -0.0002474 & 0.0010912 \\
\cline { 2 - 8 } & SIZE & -0.0028834 & 0.0049298 & -0.58 & 0.559 & -0.0125457 & 0.0067789 \\
\cline { 2 - 8 } & LEV & 0.0468296 & 0.0176203 & 2.66 & 0.008 & 0.0122945 & 0.0813646 \\
\cline { 2 - 8 } & SG & 0.0121524 & 0.0071127 & 1.71 & 0.088 & -0.0017883 & 0.0260931 \\
\cline { 2 - 8 } & Constant & 0.079546 & 0.0717759 & 1.11 & 0.268 & -0.0611322 & 0.2202242 \\
\hline
\end{tabular}

We started our analysis by estimating common effect model carried out by standard errors. The results (reported in Appendix A) indicated that coefficient of cash flow was highly significant, the coefficient of cash flow volatility $(\mathrm{CVCF})$ and leverage were also positively highly significant. The results were in conformity in Almeida et al. (2004) and it indicated that Pakistani firms hold more cash out of their cash flows. Further the significance, as cash flow volatility indicates that Pakistani firms hold more cash when they foresee risk in their operating cash flows. Also leverage was highly significant because it represents long-term debt and is used for the firms for its operating expenses. However, firms take more leverage it has significance. The significance of leverage coefficient indicates that the long-term debt will eventually need to be paid back using this cash. Also, to protect firms from default risk firms will hold more cash. However, unusually the high $t$ and $p$ values led us to check over data for heteroskedasticity. The Breusch-Pagan/ Cook-Weisberg hettest revealed the p-value of 0.0000 which indicated the presence of outlier in our data or in other words our data was homoscedasticity. 
The heteroskedasticity test prompted us to estimate the panel data analytical model with robust standard errors for robust and generalizable results (Gujarati 2003). Outlays all these results are results of all panel data analytical model that is evident from table 3. Common effect model with robust estimating standard errors changes the whole situation. Cash flow to cash sensitivity persistence which is evident from p-values of cash flow variables. However, cash flow volatility become insignificant but remained positive. As is indicated in the methodology we will not only rely on common effect model that prompted us to estimate fixed effect model with robust standard errors. The model indicated that variables of cash flow, cash flow volatility (CVCF) and leverage were positively significant while size was negatively significant. These results were in contradiction with random effect model that indicated the coefficient of cash flow volatility and size was insignificant. Since both models give contradictory results, therefore we used Haussmann test (Appendix A). The p-value (0.0073) of Haussmann test indicates that we accept $\mathrm{H}_{1}$ in which we stated that the results of fixed effect model will be accepted. Thus, Haussmann test buttress that we accept the results obtained by estimating fixed model. The results of fixed effect model confirmed Almeida et al. (2004) conclusion in Pakistani context. Momentous significant coefficient cash flow indicates that Pakistani firms hold more cash out of their cash flows and consequently will undertake positive NPV Projects using these cash reserves. As significant positive coefficient of cash flow volatility (CVCF) indicates that overall firms try to hold more cash when there is more risk. This result too is the conformity to literature review. Precautionary motive of cash holding creates a positive relationship between cash holdings and cash flow volatility and a negative relationship between current investments and cash flow volatility for a financially constrained firm. There is no systematic relationship between cash holdings, investment levels and future cash flow volatility. In other words, a financially unconstrained firm has no precautionary motive for cash holdings. However, the coefficient of size was significant but negative. This indicates that as the size of the firm increases they hold less cash and vice-versa. These results seems to be inconformity with Fazzari (1988) who also indicated that as the size of the firm increases their information are symmetry, lower and consequently they hold less cash. Zingales (1997) gave the opposite prediction. Thus, we will investigate these variables in more detail in later section. Leverage is also positive and significant for two reasons. One reason is that leverage here indicates the long-term debt which is synonymous to cash. Thus, the increase in the cash balances of the firm. However, long-term debt eventually has to be paid off and its increase will prompt to hold more cash to avoid default risk. The sales growth which is the proxy of sales of the firm is insignificant but positive which indicates that Pakistani manufacturing firms hold cash despite of their growth opportunity.

\subsection{CVCF Based Classifications}

For further analysis we have classified all firms into constrained and unconstrained categories based on their cash flow volatility. The firms with higher than median cash flow volatility were in constrained category and vice versa.

\subsubsection{CVCF Constrained Firms Results}

The results of common effect model carried out with standard errors (reported in Appendix B) indicate that the coefficients of cash flow, cash flow volatility, size and leverage were positively significant. We tested data for heteroskedasticity due to high $t$ and $\mathrm{p}$ values. The Breusch-Pagan/ Cook-Weisberg hettest shown the $\mathrm{p}$ value of 0.0000 which indicated that our data was heteroskedastic. Thus, we had to conduct all tests using robust standard errors.

TABLE 4

PANEL A

\begin{tabular}{|c|c|c|c|c|c|c|c|}
\hline \multicolumn{10}{|c|}{ PANEL A } \\
\hline \multirow{4}{*}{$\begin{array}{c}\text { Common } \\
\text { Effect } \\
\text { Model }\end{array}$} & Variables & Coefficient & $\begin{array}{c}\text { Robust } \\
\text { Std. Err. }\end{array}$ & $\mathbf{T}$ & $\mathbf{P}>|\mathbf{t}|$ & \multicolumn{2}{|c|}{$[\mathbf{9 5 \%}$ Conf. Interval] } \\
\cline { 2 - 8 } & CF & 0.2313701 & 0.0620829 & 3.73 & 0 & 0.1095324 & 0.3532077 \\
\cline { 2 - 8 } & CVCF & 0.0011096 & 0.0006547 & 1.69 & 0.09 & -0.0001753 & 0.0023944 \\
\cline { 2 - 8 } & SIZE & 0.0081015 & 0.0060945 & 1.33 & 0.184 & -0.003859 & 0.020062 \\
\cline { 2 - 8 } & LEV & 0.0826037 & 0.018883 & 4.37 & 0 & 0.0455459 & 0.1196615 \\
\cline { 2 - 8 } & SG & -0.0059738 & 0.0129391 & -0.46 & 0.644 & -0.0313667 & 0.0194191 \\
\cline { 2 - 8 } & Constant & -0.0777511 & 0.0866605 & -0.9 & 0.37 & -0.2478222 & 0.0923201 \\
\hline
\end{tabular}


Impact Of Cashflow Volatility On Cash-Cash Flow Sensitivity Of Pakistani Firms

\begin{tabular}{|c|c|c|c|c|c|c|c|}
\hline & Variables & Coefficient & $\begin{array}{c}\text { Robust } \\
\text { Std. Err. }\end{array}$ & T & P>|t| & \multicolumn{2}{|c|}{ [95\% Conf. Interval] } \\
\cline { 2 - 8 } & CF & 0.0707023 & 0.0257916 & 2.74 & 0.006 & 0.0200538 & 0.1213508 \\
\cline { 2 - 8 } Fixed & CVCF & 0.0002172 & 0.0000942 & 2.31 & 0.021 & 0.0000323 & 0.0004021 \\
\cline { 2 - 8 } Effect & SIZE & -0.0210254 & 0.0138968 & -1.51 & 0.131 & -0.0483155 & 0.0062647 \\
\cline { 2 - 8 } & LEV & 0.0402473 & 0.006837 & 5.89 & 0 & 0.026821 & 0.0536736 \\
\cline { 2 - 8 } & SG & 0.0200267 & 0.0127879 & 1.57 & 0.118 & -0.0050856 & 0.0451389 \\
\cline { 2 - 8 } & Constant & 0.3753153 & 0.1976558 & 1.9 & 0.058 & -0.0128335 & 0.763464 \\
\hline
\end{tabular}

\begin{tabular}{|c|c|c|c|c|c|c|c|}
\hline & Variables & Coefficient & $\begin{array}{c}\text { Robust } \\
\text { Std. Err. }\end{array}$ & $\mathbf{Z}$ & $\mathbf{P}>|\mathbf{z}|$ & \multicolumn{2}{|c|}{$[\mathbf{9 5 \%}$ Conf. Interval] } \\
\cline { 2 - 8 } Random & $\mathbf{C F}$ & 0.1173179 & 0.0491629 & 2.39 & 0.017 & 0.0209604 & 0.2136755 \\
\cline { 2 - 8 } $\begin{array}{c}\text { Effect } \\
\text { Model }\end{array}$ & $\mathbf{C V C F}$ & 0.0004627 & 00.0003646 & 1.27 & 0.204 & -0.0002519 & 0.0011773 \\
\cline { 2 - 8 } & SIZE & 0.0021793 & 0.0066791 & 0.33 & 0.744 & -0.0109115 & 0.01527 \\
\cline { 2 - 8 } & LEV & 0.053548 & 0.0197808 & 2.71 & 0.007 & 0.0147784 & 0.0923175 \\
\cline { 2 - 8 } & SG & 0.0142819 & 0.0089098 & 1.6 & 0.109 & -0.003181 & 0.0317448 \\
\cline { 2 - 8 } & Constant & 0.0191458 & 0.0965323 & 0.2 & 0.843 & -0.170054 & 0.2083456 \\
\hline
\end{tabular}

Panel A of table 4 shows common effect model with robust standard errors for constrained firms. Cash flow and leverage results reveal that they are positive and highly significant. However, cash flow volatility and size are positive but insignificant.

For robustness and generalizability we have used fixed and random effect models with robust standard errors. A result of fixed effect model indicates that coefficients of cash flow, cash flow volatility and leverage are positively significant whereas coefficient of sales growth is positive but insignificant but size is negatively insignificant. However, the results of random effect model revealed that only cash flow and leverage were positive and significant. This conflict between two models is resolved by conducting Haussmann test. The results of Haussmann test revealed that we accept $\mathrm{H}_{0}$ in which we stated that the results of random effect model will be accepted.

The results of random effect model suggest that CVCF constrained firms save more cash out of their cash flows. This is in accordance with the findings of Han \& Qiu (2007). Further it's in accordance with Almeida et al. (2004) that suggest behavior of firms to hold more cash out of their cash flows when faced with uncertainty. Further, the leverage has significant coefficients that indicate that firms will save more cash to make debt payments and avoid default risk.

\subsubsection{CVCF Unconstrained Firms Results}

The results of common effect model carried out with standard errors (reported in Appendix B) indicate that the coefficients of cash flow and sales growth were positively significant. We tested data for heteroskedasticity due to high $t$ and $p$ values. The Breusch-Pagan/ Cook-Weisberg hettest shown the $p$-value of 0.0000 which indicated that our data was heteroskedastic. Thus, we had to conduct all tests using robust standard errors.

TABLE 5

PANEL B

\begin{tabular}{|c|c|c|c|c|c|c|c|}
\hline \multicolumn{7}{|c|}{ PANEL B } \\
\hline \multicolumn{1}{|c|}{ CVCF Unconstrained Firms } \\
\hline \multirow{4}{*}{\begin{tabular}{c} 
Commo \\
n Effect \\
\cline { 2 - 8 } Model
\end{tabular}} & Variables & Coefficient & $\begin{array}{c}\text { Robust } \\
\text { Std. Err. }\end{array}$ & $\mathbf{T}$ & $\mathbf{P}>|\mathbf{t}|$ & \multicolumn{2}{|c|}{$[\mathbf{9 5 \%}$ Conf. Interval] } \\
\cline { 2 - 8 } & CVCF & 0.0970467 & 0.0577762 & 1.68 & 0.093 & -0.0163391 & 0.2104325 \\
\cline { 2 - 8 } & SIZE & -0.6818541 & 0.3180888 & 2.14 & 0.032 & 0.0576043 & 1.306104 \\
\cline { 2 - 8 } & LEV & -0.00165775 & 0.002262 & -0.58 & 0.56 & -0.0057567 & 0.0031217 \\
\cline { 2 - 8 } & SG & 0.0166254 & 0.0126958 & 1.31 & 0.191 & -0.0082902 & 0.0415411 \\
\cline { 2 - 8 } & Constant & 0.0264043 & 0.0348944 & 0.76 & 0.449 & -0.0420761 & 0.0948846 \\
\hline
\end{tabular}


Impact Of Cashflow Volatility On Cash-Cash Flow Sensitivity Of Pakistani Firms

\begin{tabular}{|c|c|c|c|c|c|c|c|}
\hline \multirow{7}{*}{$\begin{array}{l}\text { Fixed } \\
\text { Effect } \\
\text { Model }\end{array}$} & \multirow{2}{*}{$\begin{array}{c}\text { Variables } \\
\mathbf{C F}\end{array}$} & \multirow{2}{*}{$\begin{array}{c}\text { Coefficient } \\
0.0693391\end{array}$} & \multirow{2}{*}{$\begin{array}{c}\begin{array}{c}\text { Robust } \\
\text { Std. Err. }\end{array} \\
0.0252096\end{array}$} & \multirow{2}{*}{$\frac{\mathbf{T}}{2.75}$} & \multirow{2}{*}{$\begin{array}{l}\mathbf{P}>|\mathbf{t}| \\
0.006\end{array}$} & \multicolumn{2}{|c|}{ [95\% Conf. Interval] } \\
\hline & & & & & & 0.0198361 & 0.118842 \\
\hline & CVCF & 0.0502464 & 0.2120655 & 0.24 & 0.813 & -0.3661769 & 0.4666697 \\
\hline & SIZE & -0.0027488 & 0.0034903 & -0.79 & 0.431 & -0.0096026 & 0.004105 \\
\hline & LEV & 0.0132472 & 0.034404 & 0.39 & 0.7 & -0.0543104 & 0.0808047 \\
\hline & SG & 0.0070529 & 0.0028996 & 2.43 & 0.015 & 0.0013591 & 0.0127466 \\
\hline & Constant & 0.0553476 & 0.050802 & 1.09 & 0.276 & -0.0444099 & 0.1551051 \\
\hline
\end{tabular}

\begin{tabular}{|c|c|c|c|c|c|c|c|}
\hline & Variables & Coefficient & $\begin{array}{c}\text { Robust } \\
\text { Std. Err. }\end{array}$ & $\mathbf{Z}$ & $\mathbf{P}>|\mathbf{z}|$ & \multicolumn{2}{|c|}{$[\mathbf{9 5 \%}$ Conf. Interval] } \\
\cline { 2 - 8 } & $\mathbf{C F}$ & 0.0750644 & 0.0213483 & 3.52 & 0 & 0.0332225 & 0.1169064 \\
\cline { 2 - 8 } Random \\
Effect \\
Model & CVCF & 0.0614647 & 0.1776054 & 0.35 & 0.729 & -0.2866354 & 0.4095648 \\
\cline { 2 - 8 } & SIZE & -0.0021752 & 0.0038723 & -0.56 & 0.574 & -0.0097647 & 0.0054143 \\
\cline { 2 - 8 } & LEV & 0.0092112 & 0.0270904 & 0.34 & 0.734 & -0.043885 & 0.0623074 \\
\cline { 2 - 8 } & SG & 0.0077851 & 0.002451 & 3.18 & 0.001 & 0.0029812 & 0.0125891 \\
\cline { 2 - 8 } & Constant & 0.0563181 & 0.0560377 & 1.01 & 0.315 & -0.0535138 & 0.16615 \\
\hline
\end{tabular}

Results reported in Panel B of table 5 shows common effect model with robust standard errors for unconstrained firms. Cash flow volatility result reveals that this is positively significant whereas cash flow and sales growth are positivebut insignificant. However, size and leverage are negative but alsoinsignificant.

For robustness and generalizability we have used fixed and random effect models with robust standard errors. Results of fixed effect model indicates that coefficients of cash flow and sales growth are positively significant whereas coefficients of cash flow volatility and leverage were positively insignificant but firm size is negatively insignificant. On the other hand, the results of random effect model revealed that only cash flow and sales growth were positive and significant. This conflict between two models is resolved by conducting Haussmann test. The results of Haussmann test revealed that we accept $\mathrm{H}_{1}$ in which we stated that the results of fixed effect model will be accepted.

The results of fixed effect model suggest that CVCF unconstrained firms have enough financing capacity to finance the first-best investments. Cash flow and sales growth results reveal the positive significance. However, there is no systematic relationship between the financially unconstrained firm's optimal cash holding and marginal increases in cash flow volatility. This result is analogous to Modigliani and Miller's (1958) arguments which suggest that financial policy is irrelevant to real decisions, so cash holding is unknown for unconstrained firms.

The significance of sales growth indicates that firms will need cash to finance their growth (Opler et al. 1999). The significance of cash flow indicates that Pakistani firms, though unconstrained, prefer to finance their activities with internal funds. These results are in accordance with Zingales (1997).

\subsection{Size Based Classifications}

Moreover, we have classified all firms into constrained and unconstrained classifications based on their size. The firm's size higher than median was in unconstrained group whereas firm's size lesser than median was in constrained group.

\subsubsection{Size Constrained Firms Results}

The results of common effect model carried out with standard errors (reported in Appendix C) indicate that the coefficients of cash flow, cash flow volatility and size were positively significant. Due to high $t$ and $p$ values we implement heteroskedasticity test in order to check data in which Breusch-Pagan/ Cook-Weisberg hettest shown the p-value of 0.0000 which indicated that our data was heteroskedastic. Thus, we had to conduct all tests using robust standard errors.

TABLE 6

\begin{tabular}{|c|c|c|c|c|c|c|c|}
\hline \multicolumn{8}{|c|}{ PANEL A } \\
\hline \multicolumn{8}{|c|}{ Size Constrained Firms } \\
\hline \multirow{4}{*}{$\begin{array}{c}\text { Common } \\
\text { Effect } \\
\text { Model }\end{array}$} & Variables & Coefficient & $\begin{array}{c}\text { Robust } \\
\text { Std. Err. }\end{array}$ & $\mathbf{T}$ & $\mathbf{P}>|\mathbf{t}|$ & \multicolumn{2}{|c|}{ [95\% Conf. Interval] } \\
\hline & $\mathbf{C F}$ & 0.474665 & 0.1004332 & 4.73 & 0 & 0.2775649 & 0.671765 \\
\hline & CVCF & 0.0761344 & 0.0458982 & 1.66 & 0.097 & -0.0139408 & 0.1662096 \\
\hline & SIZE & 0.0099257 & 0.0041258 & 2.41 & 0.016 & 0.0018288 & 0.0180227 \\
\hline
\end{tabular}


Impact Of Cashflow Volatility On Cash-Cash Flow Sensitivity Of Pakistani Firms

\begin{tabular}{|c|c|c|c|c|c|c|c|}
\hline LEV & -0.0861787 & 0.0280637 & -3.07 & 0.002 & -0.1412537 & -0.0311038 \\
\cline { 2 - 8 } & SG & 0.0119559 & 0.0090052 & 1.33 & 0.185 & -0.0057167 & 0.0296285 \\
\cline { 2 - 8 } & Constant & -0.1335767 & 0.0597586 & -2.24 & 0.026 & -0.2508529 & -0.0163004 \\
\hline
\end{tabular}

\begin{tabular}{|c|c|c|c|c|c|c|c|}
\hline \multirow{4}{*}{$\begin{array}{c}\text { Fixed } \\
\text { Effect }\end{array}$} & Variables & Coefficient & $\begin{array}{c}\text { Robust } \\
\text { Std. Err. }\end{array}$ & $\mathbf{T}$ & $\mathbf{P}>|\mathbf{t}|$ & \multicolumn{2}{|c|}{$[\mathbf{9 5 \%}$ Conf. Interval] } \\
\cline { 2 - 8 } Model & $\mathbf{C F}$ & 0.3538267 & 0.0847866 & 4.17 & 0 & 0.187369 & 0.5202844 \\
\cline { 2 - 8 } & CVCF & 0.014324 & 0.0184212 & 0.78 & 0.437 & -0.0218415 & 0.0504895 \\
\cline { 2 - 8 } & SIZE & -0.0176742 & 0.0145515 & -1.21 & 0.225 & -0.0462424 & 0.0108941 \\
\cline { 2 - 7 } & LEV & 0.0279678 & 0.0272893 & 1.02 & 0.306 & -0.0256082 & 0.0815437 \\
\cline { 2 - 7 } & SG & 0.0178548 & 0.0058834 & 3.03 & 0.002 & 0.0063043 & 0.0294054 \\
\cline { 2 - 8 } & Constant & 0.3004444 & 0.2322113 & 1.29 & 0.196 & -0.1554455 & 0.7563343 \\
\hline
\end{tabular}

\begin{tabular}{|c|c|c|c|c|c|c|c|}
\hline & Variables & Coefficient & $\begin{array}{c}\text { Robust } \\
\text { Std. Err. }\end{array}$ & $\mathbf{Z}$ & $\mathbf{P}>|\mathbf{z}|$ & \multicolumn{2}{|c|}{ [95\% Conf. Interval] } \\
\cline { 2 - 8 } & $\mathbf{C F}$ & 0.4126562 & 0.1053124 & 3.92 & 0 & 0.2062477 & 0.6190647 \\
\cline { 2 - 8 } Random \\
$\begin{array}{c}\text { Effect } \\
\text { Model }\end{array}$ & $\mathbf{C V C F}$ & 0.0282193 & 0.022786 & 1.24 & 0.216 & -0.0164404 & 0.072879 \\
\cline { 2 - 8 } & SIZE & 0.0095487 & 0.0054724 & 1.74 & 0.081 & -0.001177 & 0.0202744 \\
\cline { 2 - 8 } & LEV & -0.037954 & 0.0265869 & -1.43 & 0.153 & -0.0900634 & 0.0141554 \\
\cline { 2 - 8 } & SG & 0.0169861 & 0.0055971 & 3.03 & 0.002 & 0.0060159 & 0.0279562 \\
\cline { 2 - 8 } & Constant & -0.1247212 & 0.0861484 & -1.45 & 0.148 & -0.293569 & 0.0441266 \\
\hline
\end{tabular}

Panel A of table 6 shows common effect model with robust standard errors for constrained firms. Cash flow and size results reveal that they are positive and significant whereas leverage is negative and significant. However, cash flow volatility and sales growth are positive but insignificant.

For robustness and generalizability we have used fixed and random effect models with robust standard errors. A result of fixed effect model indicates that coefficients of cash flow and sales growth are positively significant whereas coefficients of cash flow volatility and leverage are positive but insignificant while size is negatively insignificant. However, the results of random effect model revealed that cash flow and sales growth are positive and significant. While cash flow volatility and size showed positive insignificant results whereas leverage is negative but insignificant. This conflict between two models is resolved by conducting Haussmann test. Thus, the results of Haussmann test revealed that we accept $\mathrm{H}_{0}$ in which we stated that the results of random effect model will be accepted.

The results of random effect model indicates that size constrained firms are reliant on their cash holdings. The significance of sales growth indicates that they need their cash to finance their growth opportunities. The results are in conformity with Fazzari et al. (1988), Almeida et al. (2004) and Han \& Qiu (2007).

\subsubsection{Size Unconstrained Firms Results}

The results of common effect model carried out with standard errors (reported in Appendix C) indicate that the coefficients of cash flow, cash flow volatility and leverage were positively significant. Moreover firm's size is negatively significant while sales growth is negative but insignificant. We tested data for heteroskedasticity due to high $t$ and $p$ values. The Breusch-Pagan/ Cook-Weisberg hettest shown the $p$-value of 0.0000 which indicated that our data was heteroskedastic. Thus we had to conduct all tests using robust standard errors.

TABLE 7

PANEL B

\begin{tabular}{|c|c|c|c|c|c|c|c|}
\hline \multicolumn{7}{|c|}{ PANEL B } \\
\hline \multirow{4}{*}{$\begin{array}{c}\text { Size Unconstrained Firms } \\
\text { Common } \\
\text { Effect } \\
\text { Model }\end{array}$} & Variables & Coefficient & $\begin{array}{c}\text { Robust } \\
\text { Std. Err. }\end{array}$ & $\mathbf{T}$ & $\mathbf{P}>|\mathbf{t}|$ & \multicolumn{2}{|c|}{$[\mathbf{9 5 \%}$ Conf. Interval] } \\
\cline { 2 - 8 } & CF & 0.1614678 & 0.0729955 & 2.21 & 0.027 & 0.0182141 & 0.3047216 \\
\cline { 2 - 8 } & CVCF & 0.0010495 & 0.0006977 & 1.5 & 0.133 & -0.0003197 & 0.0024187 \\
\cline { 2 - 8 } & SIZE & -0.0235445 & 0.0116565 & -2.02 & 0.044 & -0.0464204 & -0.0006685 \\
\cline { 2 - 8 } & LEV & 0.0756692 & 0.0196742 & 3.85 & 0 & 0.0370585 & 0.1142799 \\
\cline { 2 - 8 } & SG & -0.0040206 & 0.0146966 & -0.27 & 0.784 & -0.0328628 & 0.0248216 \\
\cline { 2 - 8 } & Constant & 0.3177554 & 0.153366 & 2.07 & 0.039 & 0.0167743 & 0.6187364 \\
\hline
\end{tabular}


Impact Of Cashflow Volatility On Cash-Cash Flow Sensitivity Of Pakistani Firms

\begin{tabular}{|c|c|c|c|c|c|c|c|}
\hline \multirow{7}{*}{$\begin{array}{l}\text { Fixed } \\
\text { Effect } \\
\text { Model }\end{array}$} & Variables & Coefficient & $\begin{array}{l}\text { Robust } \\
\text { Std. Err. }\end{array}$ & $\mathbf{T}$ & $\mathbf{P}>|\mathbf{t}|$ & \multicolumn{2}{|c|}{ [95\% Conf. Interval] } \\
\hline & $\mathbf{C F}$ & 0.0474312 & 0.0225641 & 2.1 & 0.036 & 0.0031319 & 0.0917305 \\
\hline & CVCF & 0.0002705 & 0.0000899 & 3.01 & 0.003 & 0.0000941 & 0.0004469 \\
\hline & SIZE & 0.0064571 & 0.0110477 & 0.58 & 0.559 & -0.0152326 & 0.0281468 \\
\hline & LEV & 0.037268 & 0.0073366 & 5.08 & 0 & 0.0228642 & 0.0516717 \\
\hline & SG & 0.0115601 & 0.0120535 & 0.96 & 0.338 & -0.0121042 & 0.0352244 \\
\hline & Constant & -0.0473306 & 0.1430032 & -0.33 & 0.741 & -0.3280844 & 0.2334232 \\
\hline
\end{tabular}

\begin{tabular}{|c|c|c|c|c|c|c|c|}
\hline & Variables & Coefficient & $\begin{array}{c}\text { Robust } \\
\text { Std. Err. }\end{array}$ & $\mathbf{Z}$ & $\mathbf{P}>|\mathbf{z}|$ & \multicolumn{2}{|c|}{ [95\% Conf. Interval] } \\
\cline { 2 - 8 } & $\mathbf{C F}$ & 0.0728808 & 0.0494502 & 1.47 & 0.141 & -0.0240398 & 0.1698014 \\
\cline { 2 - 8 } Random \\
$\begin{array}{c}\text { Effect } \\
\text { Model }\end{array}$ & $\mathbf{C V C F}$ & 0.0003274 & 0.0003346 & 0.98 & 0.328 & -0.0003283 & 0.0009831 \\
\cline { 2 - 8 } & SIZE & -0.0263858 & 0.0131387 & -2.01 & 0.045 & -0.0521372 & -0.0006343 \\
\cline { 2 - 8 } & LEV & 0.0482545 & 0.0174904 & 2.76 & 0.006 & 0.0139739 & 0.082535 \\
\cline { 2 - 8 } & SG & 0.0083659 & 0.0111513 & 0.75 & 0.453 & -0.0134903 & 0.0302221 \\
\cline { 2 - 8 } & Constant & 0.3741279 & 0.174701 & 2.14 & 0.032 & 0.0317202 & 0.7165356 \\
\hline
\end{tabular}

Results reported in Panel B of table 7 shows common effect model with robust standard errors for unconstrained firms. Cash flow and leverage results reveal that they are positively significant whereas cash flow volatility is positive but insignificant. However, size and sales growth are negative but insignificant.

For robustness and generalizability we have used fixed and random effect models with robust standard errors. Results of fixed effect model indicates that coefficients of cash flow, cash flow volatility and leverage are positively significant whereas coefficients of size and sales growth were also positive but insignificant. On the other hand, the results of random effect model revealed that leverage is positive and significant but cash flow, cash flow volatility and sales growth were also positive but insignificant. This conflict between two models is resolved by conducting Haussmann test. The results of Haussmann test revealed that we accept $\mathrm{H}_{1}$ in which we stated that the results of fixed effect model will be accepted.

The result of fixed effect model indicates that sized unconstrained firms show more investment cash flow sensitivity. Further, the coefficient of cash flow volatility (CVCF) and leverage are positive and significant. The cash flow volatility appears to have significant coefficient because these unconstrained firms are highly leveraged as indicated by significant coefficient of leverage. Thus, more cash is needed for precautionary motive that includes debt servicing.

\section{Conclusion}

The results reveal that coefficient of cash flow was significant which indicates that Pakistani firms hold more cash out of their cash flows and consequently will undertake positive NPV Projects using these cash reserves. Coefficient of cash flow volatility (CVCF) was positive and significant which indicates that overall firms try to hold more cash when there is more risk. In some instances (especially in unconstrained firms) leverage was found significant. This indicated that higher the level of debt, more will firms hold cash to avoid bankruptcy.

For further in depth analysis we have classified all firms into constrained and unconstrained categories based on their cash flow volatility (CVCF). The results of random effect model suggest that CVCF constrained firms save more cash out of their cash flows which is in accordance with the findings of Han \& Qiu (2007). Further it's in accordance with Almeida et al. (2004) that suggest behavior of firms to hold more cash out of their cash flows when faced with uncertainty. Whereas leverage has significant coefficients that indicate that firms will save more cash to make debt payments and avoid bankruptcy. The results of fixed effect model suggest that CVCF unconstrained firms have enough financing capacity to finance the first-best investments. Cash flow and sales growth results reveal the positive significance. However, there is no systematic relationship between the financially unconstrained firm's optimal cash holding and marginal increases in cash flow volatility. Usually, firms hold more cash when they have more growth opportunities and are willing to take higher risks than firms with larger size and higher net working capital.

Moreover, we have classified all firms into constrained and unconstrained classifications based on their size. In size constrained firms, we accept random effect model in which cash flow and sales growth are positively significant because constrained firms hold more cash to avoid them to finance with high borrowing cost in the result of cash shortage or for investment purpose. In size unconstrained firms, we accept fixed effect model in which cash flow and cash flow volatility are positive and significant which indicates that as the size of firm will increase the firm will take more finance for growth purpose and due to which its cash flow volatility 
will also increase. Leverage is highly significant because long-term debt eventually has to be paid off and its increase will prompt us to hold more cash to avoid default risk.

Cash-cash flow sensitivity has been found in all Pakistani firms which mean that Pakistani firms hold more cash out of their cash flows. This can be seen as evidence that Pakistani firms invest in positive NPV Projects by using their internal funds. However, where the growth opportunities are limited, the cash-cash flow sensitivity is exhibited because of debt taken by these firms. Thus, as precaution to pay debt in future they hold more cash out of their cash flows. Therefore, it can be safety said that the given Pakistani economic condition and debt servicing contributes to the cash flow volatility (CVCF) of Pakistani Manufacturing Firms. These results were in conformity in Almeida et al. (2004) which indicates that Pakistani firms hold more cash out of their cash flows.

\section{References}

[1] Acharya, V., Almeida, H.,\& Campello, M. (2006).Is cash negative debt? A hedging perspective on corporate financial policies.London Business School working paper, London, England.

[2] Almeida, H., Campello, M., \& Weisbach, M.S. (2004). Cash flow sensitivity of cash, forthcoming. Journal of Finance, 59, 17771804.

[3] Autore, D., \&Kovacs, T. (2005). The pecking order theory and time-varying adverse selection costs. Working paper, Virginia Tech, Department of Finance.

[4] Chang, K., \& Noorbakhsh, A. (2006). Corporate cash holdings, foreign direct investment and corporate governance. Global Finance Journal, 16, 302-316.

[5] Cleary \& Sean (2006). International corporate investment and the relationships between financial constraint measures, forthcoming. Journal of Banking and Finance.

[6] Dittmar, A., Mahrt-Smith, J., \& Servaes, H. (2003). International corporate governance and corporate cash holdings.Journal of Financial and Quantitative Analysis, 38, 111-133.

[7] Duchin, R. (2007). Cash holdings and corporate diversification.Job Market Paper, University of Southern California, Marshall School of Business, Los Angeles, California. (90089-0311)

[8] Fazzari, S., Hubbard, R.G., \&Petersen, B.C. (1988). Financing constraints and corporate investment. Brookings Papers on Economic Activity, 141-195.

[9] Ferreira, M.A., \& Vilela, A.S. (2004). Why do firms hold cash? Evidence from EMU countries. European Financial Management, 10, 295-319.

[10] Han, S., \& Qiu, J. (2007). Corporate precautionary cash holdings. Journal of Corporate Finance, 13, 43-57.

[11] Harford, J., Mansi, S.A.,\& Maxwell, W.F. (2005).Corporate governance and firm cash holdings. Working paper, University of Washington, Virginia Tech and University of Arizona.

[12] Hofmann, C. (2006). Why New Zealand companies hold cash: An empirical analysis. Unpublished Thesis.

[13] Kalcheva, I., \& Lins, K.V.(2006).International evidence on cash holdings and expected managerial agency problems. Working paper, University of Utah.

[14] Kaplan, S., \&Zingales, L.(1997). Do financing constraints explain why investment is correlated with cash flow? Quarterly Journal of Economics, 112, 169-215.

[15] Kim, C.S., Mauer, D.C.,\& Sherman, A.E.(1998).The determinants of corporate liquidity: Theory and Evidence. Journal of Financial and Quantitative Analysis, 33, 335-359.

[16] Kusnadi, Y. (2005). Corporate governance mechanisms and corporate cash holdings. Working paper, Hong Kong University of Science and Technology.

[17] Lundstrum, L. (2003). Firm value, information problems and the internal capital market. Review of Quantitative Finance and Accounting, 21, 141-156.

[18] Mikkelson, W.H., \& Partch, M.M.(2003). Do persistent large cash reserves hinder performance? Journal of Financial and Quantitative Analysis, 38, 275-294.

[19] Modigliani, F., \& Miller, M.H.(1958). The cost of capital, corporation finance and the theory of investment.American Economic Review, 48, 261-97.

[20] Nguyen, P. (2005).How sensitive are Japanese firms to earnings risk? Evidence from cash holdings. School of Banking \& Finance, University of New South Wales, NSW 2052, Sydney, AUSTRALIA.

[21] Opler, T., Pinkowitz, L., Stulz, R., \&Williamson, R. (1999). The determinants and implications of corporate cash holdings.Journal of Financial Economics, 52, 3-46.

[22] Ozkan, A., \& Ozkan, N. (2004). Corporate cash holdings: An empirical investigation of UK companies. Journal of Banking and Finance, 28, 2103-2134.

[23] Pinkowitz, L., Stulz, R., \& Williamson, R. (2006). Does the contribution of corporate cash holdings and dividends to firm value depend on governance? A cross-country analysis. Journal of Finance, forthcoming.

\section{APPENDIX A}

All Firms

\begin{tabular}{|c|c|c|c|c|c|c|c|}
\hline & Variables & Coefficient & Std. Err. & $\mathbf{T}$ & $\mathbf{P}>|\mathbf{t}|$ & \multicolumn{2}{|c|}{ [95\% Conf. Interval] } \\
\cline { 2 - 8 } & $\mathbf{C F}$ & 0.2412641 & 0.0131569 & 18.34 & 0 & 0.2154605 & 0.2670677 \\
\cline { 2 - 8 } Regression & $\mathbf{C V C F}$ & 0.0013147 & 0.0003329 & 3.95 & 0 & 0.0006618 & 0.0019677 \\
\cline { 2 - 8 } & SIZE & 0.0040106 & 0.0021032 & 1.91 & 0.057 & -0.0001142 & 0.0081354 \\
\cline { 2 - 8 } & LEV & 0.0744388 & 0.0048063 & 15.49 & 0 & 0.0650126 & 0.083865 \\
\cline { 2 - 8 } & SG & -0.0024949 & 0.0069787 & -0.36 & 0.721 & -0.0161817 & 0.011192 \\
\cline { 2 - 8 } & Constant & -0.0403972 & 0.0305638 & -1.32 & 0.186 & -0.1003399 & 0.0195454 \\
\hline
\end{tabular}


Impact Of Cashflow Volatility On Cash-Cash Flow Sensitivity Of Pakistani Firms

\begin{tabular}{|c|c|c|c|c|c|}
\hline \multirow{4}{*}{$\begin{array}{c}\text { Haussmann } \\
\text { fe re }\end{array}$} & Variables & $\begin{array}{c}\text { Coefficients } \\
\text { fe }\end{array}$ & $\begin{array}{c}(\mathbf{B}) \\
\text { re }\end{array}$ & $\begin{array}{c}(\mathbf{b}-\mathbf{B}) \\
\text { Difference }\end{array}$ & $\begin{array}{c}\text { Sqrt(diag(V_b-V_B) } \\
\text { S.E. }\end{array}$ \\
\cline { 2 - 6 } & $\mathbf{C F}$ & 0.0684697 & 0.0995434 & -0.0310736 & 0 \\
\cline { 2 - 6 } & CVCF & 0.0002528 & 0.0004219 & -0.0001691 & 0 \\
\cline { 2 - 6 } & SIZE & -0.0175164 & -0.0028834 & -0.014633 & 0.0047379 \\
\cline { 2 - 6 } & LEV & 0.0383233 & 0.0468296 & -0.0085063 & 0 \\
\cline { 2 - 6 } & SG & 0.0136691 & 0.0121524 & 0.0015167 & 0.0026727 \\
\hline
\end{tabular}

\section{APPENDIX B}

CVCF Based Classifications

\begin{tabular}{|c|c|c|c|c|c|c|c|}
\hline \multicolumn{8}{|c|}{ PANEL A } \\
\hline \multirow{4}{*}{ Regression Constrained Firms } \\
\hline & Variables & Coefficient & Std. Err. & $\mathbf{T}$ & $\mathbf{2}>|\mathbf{t}|$ & \multicolumn{2}{|c|}{$[\mathbf{9 5 \%}$ Conf. Interval] } \\
\cline { 2 - 9 } & CF & 0.2313701 & 0.0177159 & 13.06 & 0 & 0.1966025 & 0.2661376 \\
\cline { 2 - 9 } & CVCF & 0.0011096 & 0.0004319 & 2.57 & 0.01 & 0.000262 & 0.0019571 \\
\cline { 2 - 9 } & SIZE & 0.0081015 & 0.0034713 & 2.33 & 0.02 & 0.001289 & 0.014914 \\
\cline { 2 - 9 } & LEV & 0.0826037 & 0.0065067 & 12.7 & 0 & 0.0698344 & 0.0953731 \\
\cline { 2 - 9 } & SG & -0.0059738 & 0.0118577 & -0.5 & 0.615 & -0.0292445 & 0.0172969 \\
\cline { 2 - 9 } & Constant & -0.0777511 & 0.050379 & -1.54 & 0.123 & -0.1766198 & 0.0211177 \\
\hline
\end{tabular}

\begin{tabular}{|c|c|c|c|c|c|}
\hline \multirow{7}{*}{$\begin{array}{l}\text { Haussmann } \\
\text { fe re }\end{array}$} & \multirow[b]{2}{*}{ Variables } & \multicolumn{2}{|c|}{ Coefficients } & \multirow[b]{2}{*}{$\begin{array}{c}\text { (b-B) } \\
\text { Difference }\end{array}$} & \multirow[b]{2}{*}{$\begin{array}{c}\operatorname{Sqrt}\left(\operatorname{diag}\left(\mathbf{V} \_b-\mathbf{V} \_B\right)\right) \\
\text { S.E. }\end{array}$} \\
\hline & & $\begin{array}{l}\text { (b) } \\
\text { fe }\end{array}$ & $\begin{array}{l}\text { (B) } \\
\text { re }\end{array}$ & & \\
\hline & $\mathbf{C F}$ & 0.0707023 & 0.1173179 & -0.0466157 & 0 \\
\hline & CVCF & 0.0002172 & 0.0004627 & -0.0002455 & 0 \\
\hline & SIZE & -0.0210254 & 0.0021793 & -0.0232047 & 0.0121865 \\
\hline & LEV & 0.0402473 & 0.053548 & -0.0133007 & 0 \\
\hline & SG & 0.0200267 & 0.0142819 & 0.0057447 & 0.0091731 \\
\hline
\end{tabular}

\begin{tabular}{|c|c|c|c|c|c|c|c|}
\hline \multicolumn{8}{|c|}{ PANEL B } \\
\hline \multicolumn{8}{|c|}{ CVCF Unconstrained Firms } \\
\hline \multirow{7}{*}{ Regression } & Variables & Coefficient & Std. Err. & $\mathbf{T}$ & $P>|t|$ & \multicolumn{2}{|c|}{ [95\% Conf. Interval] } \\
\hline & $\mathbf{C F}$ & 0.0970467 & 0.0327201 & 2.97 & 0.003 & 0.0328334 & 0.1612599 \\
\hline & CVCF & 0.6818541 & 0.369538 & 1.85 & 0.065 & -0.0433649 & 1.407073 \\
\hline & SIZE & -0.0013175 & 0.0017576 & -0.75 & 0.454 & -0.0047668 & 0.0021319 \\
\hline & LEV & -0.0016578 & 0.0085284 & -0.19 & 0.846 & -0.0183947 & 0.0150791 \\
\hline & SG & 0.0166254 & 0.0057301 & 2.9 & 0.004 & 0.0053801 & 0.0278708 \\
\hline & Constant & 0.0264043 & 0.026331 & 1 & 0.316 & -0.0252703 & 0.0780788 \\
\hline
\end{tabular}

\begin{tabular}{|c|c|c|c|c|c|}
\hline \multirow{7}{*}{$\begin{array}{c}\text { Haussmann } \\
\text { re fe }\end{array}$} & \multirow[b]{2}{*}{ Variables } & \multicolumn{2}{|c|}{ Coefficients } & & \\
\hline & & $\begin{array}{l}\text { (b) } \\
\text { fe }\end{array}$ & $\begin{array}{l}\text { (B) } \\
\text { re }\end{array}$ & $\begin{array}{c}\text { (b-B) } \\
\text { Difference }\end{array}$ & $\begin{array}{c}\operatorname{Sqrt}\left(\operatorname{diag}\left(\mathbf{V} \_b-V_{-} \_B\right)\right. \\
\text { S.E. }\end{array}$ \\
\hline & $\mathbf{C F}$ & 0.1173179 & 0.0693391 & 0.0479789 & 0.0422074 \\
\hline & CVCF & 0.0004627 & 0.0502464 & -0.0497837 & 0 \\
\hline & SIZE & 0.0021793 & -0.0027488 & 0.004928 & 0.0056946 \\
\hline & LEV & 0.053548 & 0.0132472 & 0.0403008 & 0 \\
\hline & SG & 0.0142819 & 0.0070529 & 0.0072291 & 0.0084248 \\
\hline
\end{tabular}


APPENDIX C

Size Based Classifications

\begin{tabular}{|c|c|c|c|c|c|c|c|}
\hline \multirow{9}{*}{ Regression } & \multirow{2}{*}{\multicolumn{7}{|c|}{$\begin{array}{c}\text { PANEL A } \\
\text { Size Constrained Firms }\end{array}$}} \\
\hline & & & & & & & \\
\hline & \multirow{2}{*}{$\frac{\text { Variables }}{\text { CF }}$} & \multirow{2}{*}{$\begin{array}{c}\text { Coefficient } \\
0.474665\end{array}$} & \multirow{2}{*}{$\begin{array}{l}\text { Std. Err. } \\
0.0317726\end{array}$} & \multirow{2}{*}{$\frac{\mathbf{T}}{14.94}$} & \multirow{2}{*}{$\frac{\mathbf{P}>|\mathbf{t}|}{0}$} & \multicolumn{2}{|c|}{ [95\% Conf. Interval] } \\
\hline & & & & & & 0.4123112 & 0.5370187 \\
\hline & CVCF & 0.0761344 & 0.0121231 & 6.28 & 0 & 0.0523428 & 0.099926 \\
\hline & SIZE & 0.0099257 & 0.0040532 & 2.45 & 0.015 & 0.0019714 & 0.0178801 \\
\hline & LEV & -0.0861787 & 0.0290893 & -2.96 & 0.003 & -0.1432665 & -0.029091 \\
\hline & SG & 0.0119559 & 0.009866 & 1.21 & 0.226 & -0.0074062 & 0.031318 \\
\hline & Constant & -0.1335767 & 0.0630616 & -2.12 & 0.034 & -0.257335 & -0.0098183 \\
\hline
\end{tabular}

\begin{tabular}{|c|c|c|c|c|c|}
\hline \multirow{7}{*}{$\begin{array}{c}\text { Haussmann } \\
\text { re fe }\end{array}$} & \multicolumn{5}{|c|}{ Coefficients } \\
\hline & Variables & $\begin{array}{l}\text { (b) } \\
\text { fe }\end{array}$ & $\begin{array}{l}\text { (B) } \\
\text { re }\end{array}$ & $\begin{array}{c}\text { (b-B) } \\
\text { Difference }\end{array}$ & $\begin{array}{c}\operatorname{Sqrt}\left(\operatorname{diag}\left(\mathbf{V} \_b-V \_B\right)\right) \\
\text { S.E. }\end{array}$ \\
\hline & $\mathrm{CF}$ & 0.4126562 & 0.3538267 & 0.0588294 & 0.0624655 \\
\hline & CVCF & 0.0282193 & 0.014324 & 0.0138953 & 0.0134112 \\
\hline & SIZE & 0.0095487 & -0.0176742 & 0.0272229 & 0 \\
\hline & LEV & -0.037954 & 0.0279678 & -0.0659217 & 0 \\
\hline & SG & 0.0169861 & 0.0178548 & -0.0008688 & 0 \\
\hline
\end{tabular}

\begin{tabular}{|c|c|c|c|c|c|c|c|}
\hline \multirow{9}{*}{ Regression } & \multicolumn{7}{|c|}{ PANEL B } \\
\hline & \multicolumn{7}{|c|}{ Size Unconstrained Firms } \\
\hline & Variables & Coefficient & Std. Err. & $\mathbf{T}$ & $\mathbf{P}>|\mathbf{t}|$ & \multicolumn{2}{|c|}{ [95\% Conf. Interval] } \\
\hline & $\mathbf{C F}$ & 0.1614678 & 0.0148204 & 10.89 & 0 & 0.1323828 & 0.1905528 \\
\hline & CVCF & 0.0010495 & 0.0003406 & 3.08 & 0.002 & 0.0003811 & 0.0017179 \\
\hline & SIZE & -0.0235445 & 0.004943 & -4.76 & 0 & -0.0332452 & -0.0138438 \\
\hline & LEV & 0.0756692 & 0.0050442 & 15 & 0 & 0.0657699 & 0.0855685 \\
\hline & SG & -0.0040206 & 0.0089964 & -0.45 & 0.655 & -0.0216761 & 0.0136349 \\
\hline & Constant & 0.3177554 & 0.0647093 & 4.91 & 0 & 0.1907632 & 0.4447475 \\
\hline
\end{tabular}

\begin{tabular}{|c|c|c|c|c|c|}
\hline \multirow{4}{*}{\begin{tabular}{c}
\multirow{4}{*}{$\begin{array}{c}\text { Haussmann } \\
\text { re fe }\end{array}$} \\
\cline { 2 - 5 }
\end{tabular}} & \multicolumn{2}{|c|}{ Coefficients } & $\begin{array}{c}\text { (b-B) } \\
\text { Difference }\end{array}$ & $\begin{array}{c}\text { Sqrt(diag(V_b-V_B)) } \\
\text { S.E. }\end{array}$ \\
\cline { 2 - 6 } & $\mathbf{C F}$ & 0.0728808 & 0.0474312 & 0.0254495 & 0.0440021 \\
\cline { 2 - 6 } & CVCF & 0.0003274 & 0.0002705 & 0.0000569 & 0.0003223 \\
\cline { 2 - 6 } & SIZE & -0.0263858 & 0.0064571 & -0.0328429 & 0.0071115 \\
\cline { 2 - 6 } & LEV & 0.0482545 & 0.037268 & 0.0109865 & 0.0158773 \\
\cline { 2 - 6 } & SG & 0.0083659 & 0.0115601 & -0.0031942 & 0 \\
\hline
\end{tabular}

